\title{
INFLUENCE OF UDDER DESCRIPTIVE LINEAR TRAITS ON COWS LIFETIME OF UKRAINIAN DAIRY BREEDS
}

\author{
Khmelnychyi Leontiy Mykhailovych \\ Doctor of Agricultural Sciences, Professor \\ Sumy National Agrarian University \\ ORCID: 0000-0001-5175-1291 \\ E-mail: khmelnychy@ukr.net \\ Vechorka Victoria Viktorivna \\ Doctor of Agricultural Sciences, Professor \\ Sumy National Agrarian University \\ ORCID: 0000-0003-4956-2074 \\ E-mail: vvvechorka@gmail.com
}

\begin{abstract}
Studies have been performed to determine the relationship between assessment of linear udder traits and lifetime of cows. Experiments were carried out in the herd of breeding farm AF "Mayak" Zolotonosha district of Cherkasy region on the number of cows of Ukrainian Red-and-White (URW) and Black-and-White (UBW) dairy breeds. Estimation of cows firstborn by conformation type was carried out according to the method of linear classification. It was found that cows with higher estimates for condition of udder morphological traits have a longer lifetime compared to animals rated lower score. The difference between cows, rated at one and nine score for trait of the front udder part attachment, was very significant and amounted 939 (URW) and 710 (UBW) days. The difference between the lowest and highest estimates on the basis of height rear udder parts attachment was 687 (URW) and 878 (UBW) days. Animals with an assessment for udder central ligament development below the average (1.4 score) were used from 1675 to 1832 (URW) and from 1535 to 1810 (UBW) days according to estimated breeds. Cows with an assessment of nine score differed by higher lifetime 2377 days, exceeding cows with the lowest score at 702 days (URW) and 2322 days with reliable excess on 785 days (UBW). The difference between the average lifetime of cows estimated at nine score and with assessment of one score for udder depth was 618 days in cows URW and in UBW - 762 days. It has been proven that cows were used longer in the herd with estimates for front teats position from five to nine score, and a significant decrease in lifetime of cows began with an estimate for this trait from three to one score. Thus, assessment of cows Ukrainian Red-and-White and Black-and-White dairy breeds by the method of linear classification confirmed that the desired development of udder morphological traits was the key to long lifetime cows in modern technological conditions of milk production.
\end{abstract}

Key words: linear estimation, Ukrainian Red-and-White dairy breed, Ukrainian Black-and-White dairy breed, udder traits, lifetime

DOI: https://doi.org/10.32845/bsnau.Ivst.2020.3.2

Specialized dairy breeds of cows created in Ukraine have undergone changes over time during selection improvement in terms of economically useful traits. First of all, changes progressed in the direction of increasing milk productivity. This was facilitated by a change in the method of reproduction, which consisted in the use at the final stage of selection, the breeding of crossbred genotypes "in itself". However, in recent years, at the absence breeding sires of their own selection have been used bull-sires Holstein breed of foreign origin. At present, the blood of domestic dairy breeds has been absorbed by the Holstein breed.

The problem with specialized high-yielding Holstein breeds around the world - reduction of productive use. Similar problems arose with high-blooded Holstein population of Ukrainian dairy breeds $[2,6,13,19,22,23]$. In this regard, productive longevity of cows Ukrainian dairy breed acquired importance. Longevity significantly determined the economic component of milk production, providing quantitative and qualitative reproduction of the herd. Scientific studies have shown that traits of productive longevity were influenced by a significant number of both genetic $[11,15,24,25,26]$ and paratypic factors $[1,5]$. Researchers, especially foreign ones, have established the existence of linear traits influence $[7,14,17,29,33]$, including udder traits, on lifetime productivity of cows $[3,20,26,27,28,30,32,34]$.
Since the level of linear traits assessment of cows influenced the indicators of their longevity, the task of our research was to study correlative variability between the assessment of udder morphological traits of cows Ukrainian Red-and-White and Black-and-White dairy breeds and their lifetime.

Materials and research methods. The experiments were carried out in the herd of breeding farm on reproduction Ukrainian Red-and-White and Black-and-White dairy breeds AF "Mayak" Zolotonosha district of Cherkasy region. Estimation of cows firstborn by conformation type was performed by the method of linear classification [21] according to the latest ICAR recommendations [31] at the age of 2-4 months after calving. Descriptive linear traits were estimated on 9-score scale. The average expression of trait was rated at five score. With biological deviations of trait towards minimum development, estimate decreased to one score, and, conversely, if the trait development approached to maximum manifestation, increased to nine score. Estimation results were processed by biometric statistic methods on PC according to formulas given by E. K. Merkuryeva [4].

Research results. The first and most important descriptive udder trait - strength of its front part attachment to the cow's abdomen (Fig. 1). 


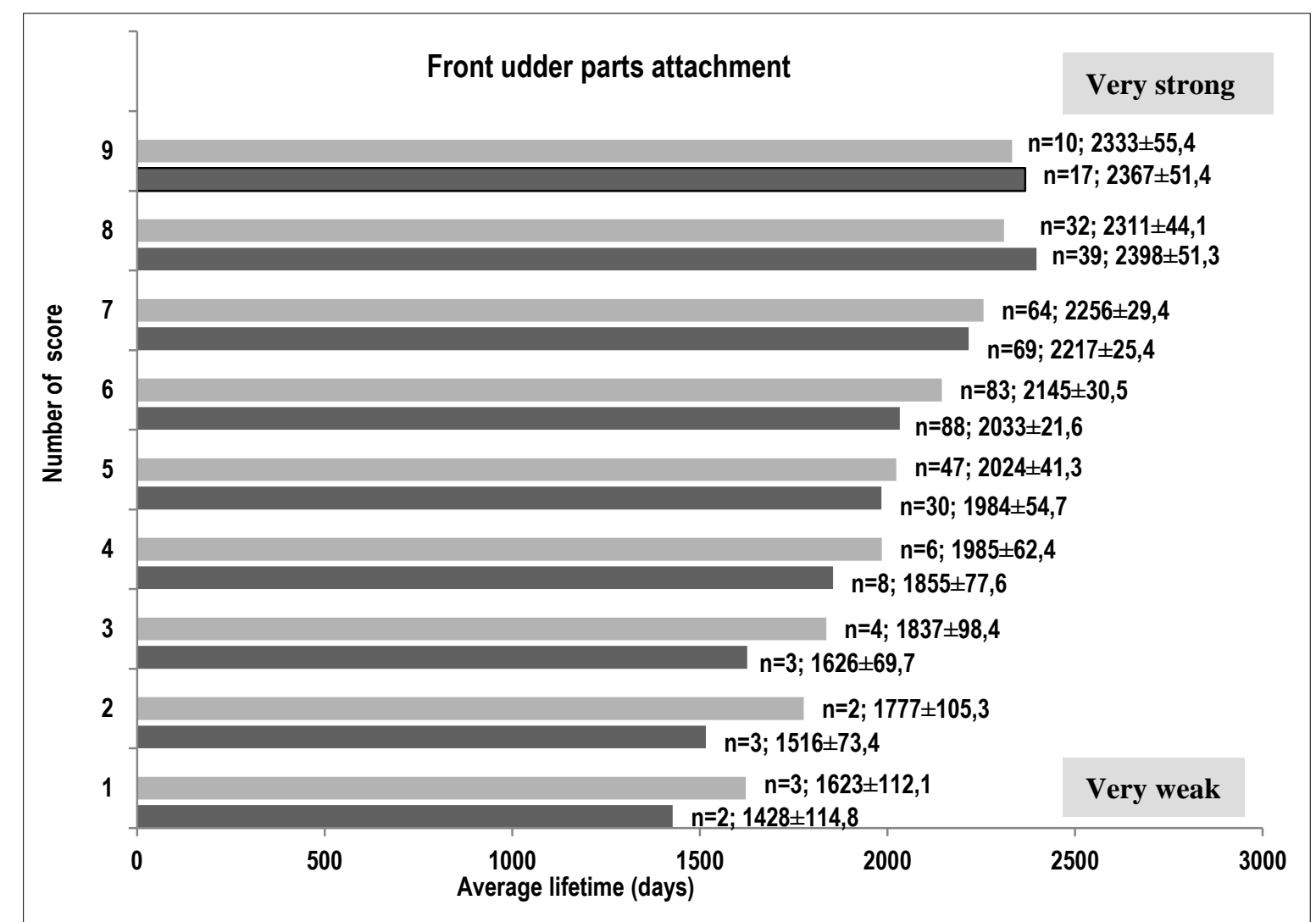

Note: here and further - - - Ukrainian Red-and-White dairy;

- Ukrainian Black-and-White dairy.

Fig. 1. Correlative variability of scoring descriptive type trait "front udder parts attachment" and cow's lifetime

The angle formed at the site of this connection was assessed. The highest score for development of this body part was received by an animal in which the udder was characterized by gradual transition front part glandular tissue to abdomen by connecting lateral ligaments with formation of an obtuse angle higher than $161^{\circ}$ [8]. The strong udder attachment was usually characterized by good development of front part and had a bath-like shape and, according to scientific studies, significantly correlated with milk productivity $[10,12,16,18,20]$. In addition, the strong attachment of front parts prevented sagging of udder with age.

Indicators of scores for front udder part attachment (Fig. 1) showed a relationship between this trait development and cow's lifetime of assessed breeds. The difference between cows, rated at one and nine score, was quite significant and amounted 939 (URW; $P<0.001$ ) and 710 (UBW; $P<0.001$ ) days.

The linear trait "height rear udder attachment" also performed a supporting function, not allowing the udder to fall with age. Desired body part development was estimated with the highest score. The difference between the lowest and highest scores on this trait, obtained from our studies in cows of experimental breeds, was 687 (URW; P <0.001) and 878 (UBW; P <0.001) days (Fig. 2). 


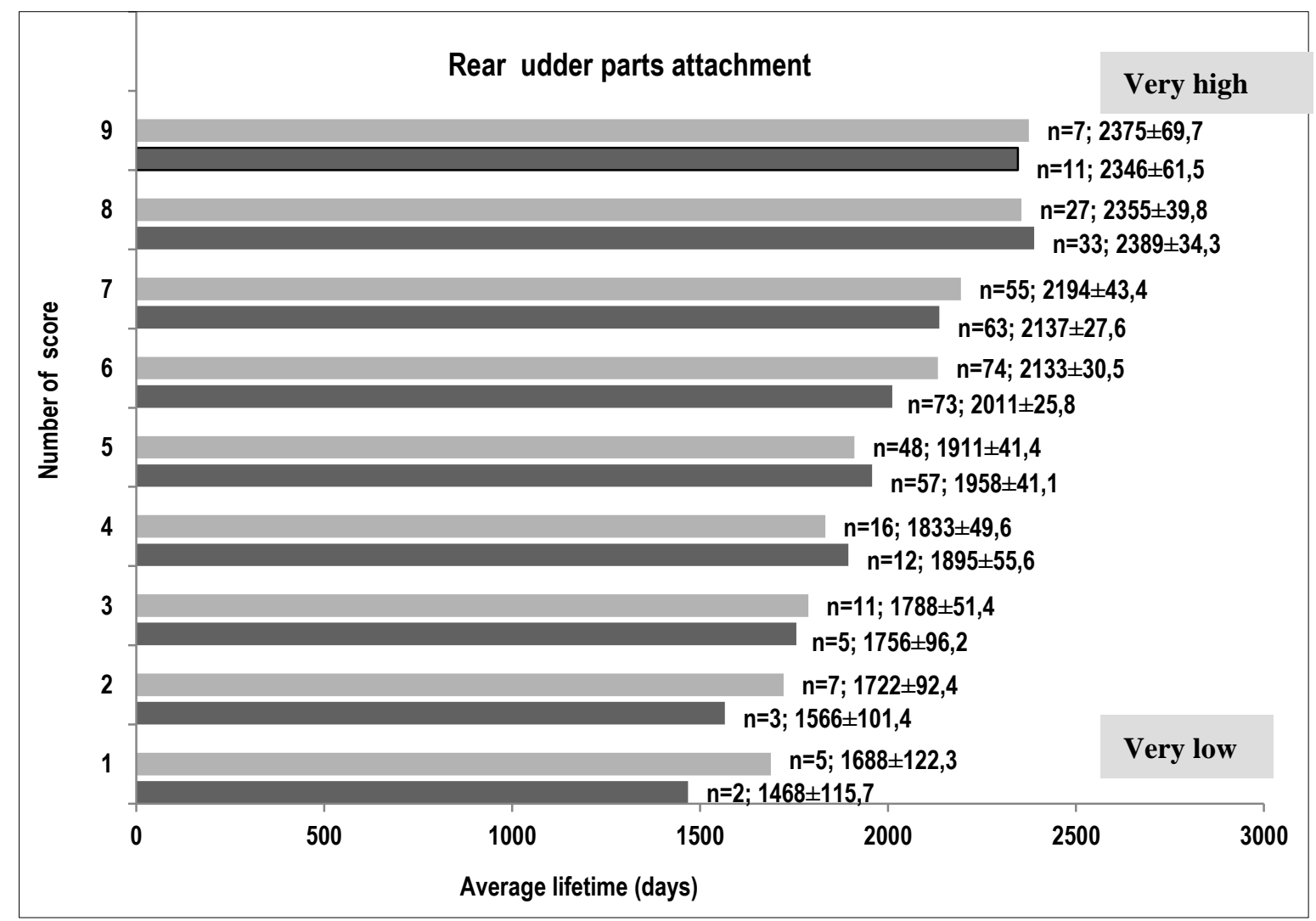

Fig. 2. Correlative variability of scoring descriptive type trait "rear udder parts attachment" and cow's lifetime

The central ligament - next linear udder trait in cows of dairy cattle, which was associated with keeping it at the appropriate height. Highly situated udder above the ground made it easier to prepare for milking and prevented cooling and injury. A high udder position with a deep, strong, well-defined and highly raised central ligament - the desired trait development with assessment in 9 score.

Histograms (Fig. 3) showed that average cow's lifetime depended largely on the assessment level for "central ligament". Animals with estimate for udder central ligament development below than average (1-4 score) were used from 1675 to 1832 (URW) and from 1535 to 1810 (UBW) days according to the estimated breeds. Cows with assessment nine score differed a higher lifetime - 2377 days, exceeding cows with the lowest score at 702 days (URW; $P<0.001$ ) and 2322 days with a significant excess by 785 days (UBW; $P<0.001$ ).
The location of udder bottom relative to the floor - very important technological trait. According to the method of linear classification, udder depth was estimated by distance between relatively conditional line drawn at the level of hock joint and udder bottom. As noted above, a deep, sagging udder will cause many inconveniences during machine milking. Will often be injured and more susceptible to disease of mastitis. Indicators of histograms (Fig. 4) showed that cows with highly placed udder were significantly less exposed to these risks and used longer in the controlled herd. The difference between the average lifetime of cows with an assessment nine score and one score for udder depth was in cows of Ukrainian Red-and-White dairy breed 618 days $(P<0.001)$, in cows of Ukrainian Black-and-White dairy - 762 days $(P<0.001)$. 


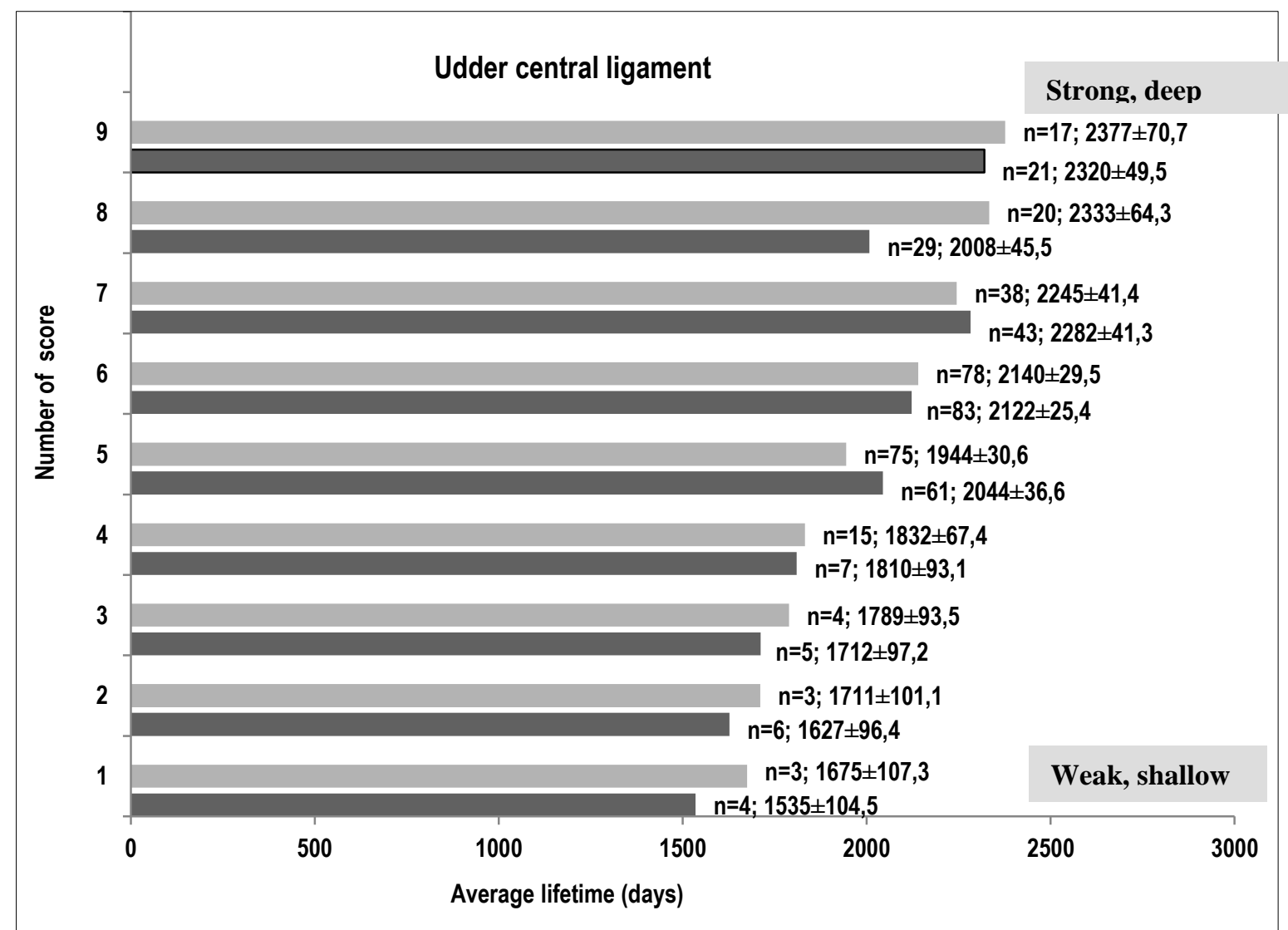

Fig. 3. Correlative variability of scoring descriptive type trait "central ligament" and cow's lifetime

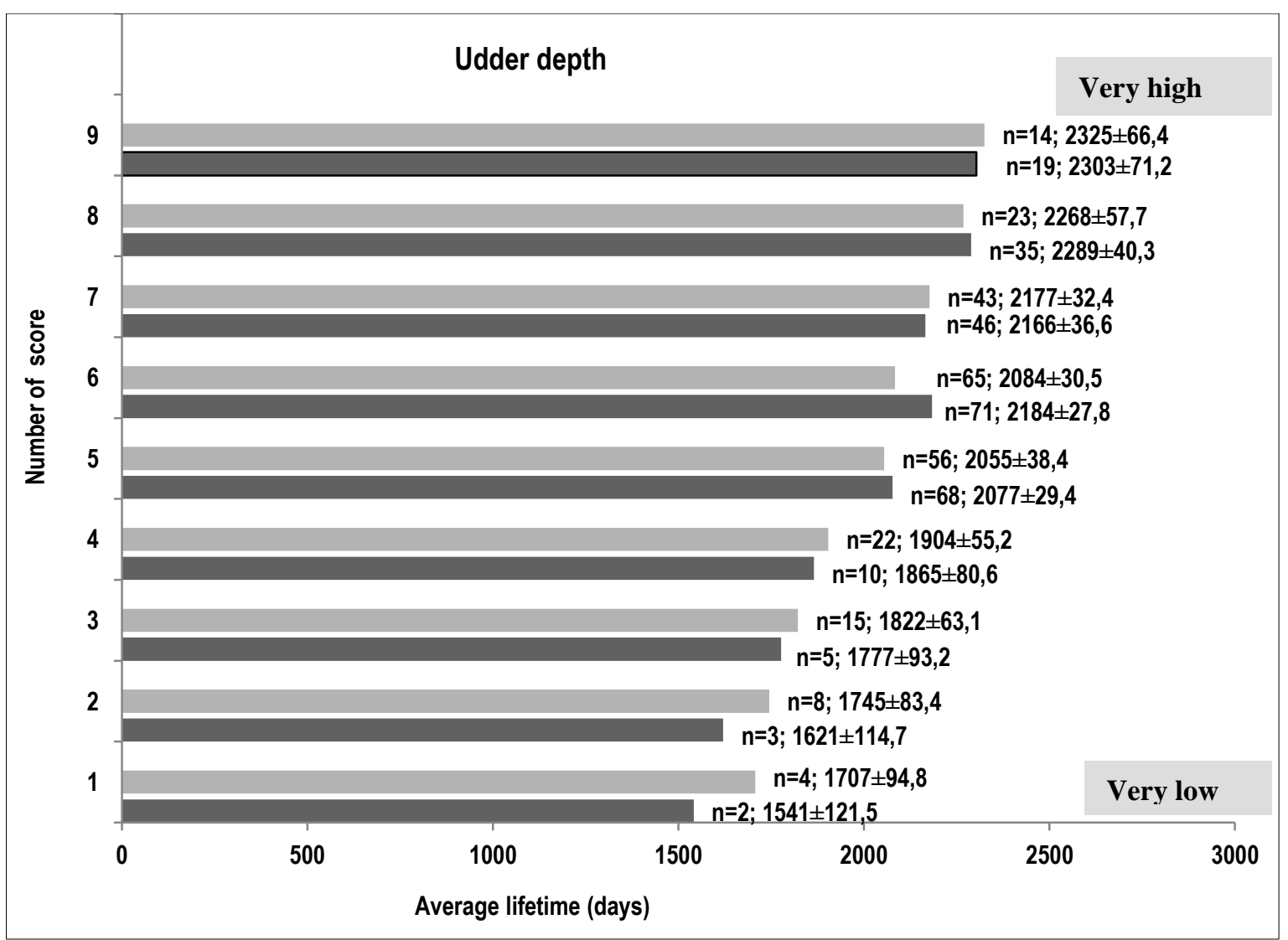

Fig. 4. Correlative variability of scoring descriptive type trait "udder depth" and cow's lifetime

The next linear udder trait - front teats position important both in terms of selection and technology (Fig. 5). 


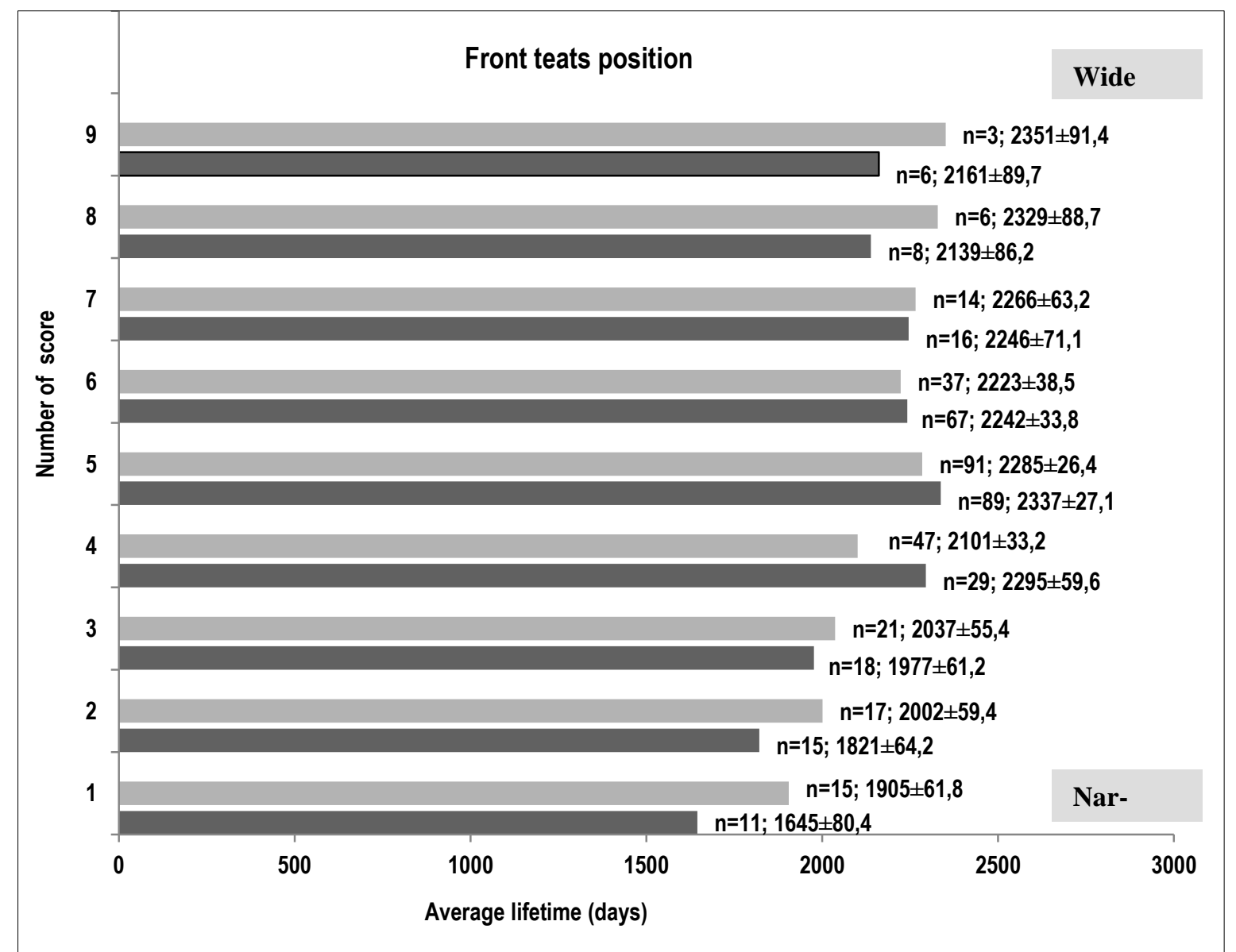

Fig. 5. Correlative variability of scoring descriptive type trait "front teats position" and cow's lifetime

Teats that have been placed at the optimal distance, placed in the center of udder parts, directed vertically down, cylindrical or conical in shape - will best meet the requirements of machine milking [9]. A very close or very wide front teats position will not be the best this trait development. Diagram results showed that cows of both breeds were used for longest time in the herd of controlled farms with estimates for the front teats position from four to nine score. A significant decrease in lifetime in cows began with estimate for this trait from three to one score.

Conclusions. Estimation cows of Ukrainian Red-andWhite and Black-and-White dairy breeds by the method of linear classification confirmed that the desired development of udder morphological traits - the key to long life of cows in modern technological conditions of milk production.

\section{References:}

1. Klimov, N. N., Tanana, L. A. and Vasilets, T. M., 2010. Vliyanie paratipicheskikh faktorov na produktivnoe dolgoletie korov belorusskoy cherno-pestroy porody [The influence of paratypical factors on productive longevity cows of Belarusian Black-and-White breed]. Uchenye zapiski uchrezhdeniya obrazovaniya "Vitebskaya ordena "Znak pocheta" gosudarstvennaya akademiya veterinarnoy meditsiny", no. 1-2, pp. 142-145.

2. Klopenko, N. I. and Stavets'ka, R. V., 2015 Henetychna determinatsiia hospodarskoho vykorystannia koriv molochnoho napriamu produktyvnosti za vbyrnoho skhreshchuvannia. [Genetic determination of cow's economic use dairy direction of productivity by absorbing crossing]. Tekhnolohiia vyrobnytstva i pererobky produktsii tvarynnytstva: Zb. nauk. prats Bilotserk. nats. ahrar. un-ta. Bila Tserkva, issue 1, pp. 23-28.

3. Mazur, N. P., 2018. Produktyvne dovholittia koriv ukrainskoi chorno-riaboi molochnoi porody riznykh eksteriernykh ta vyrobnychykh typiv [Productive longevity of cows Ukrainian Black-and-White dairy breed of various conformation and production types]. Podilskyi visnyk: silske hospodarstvo, tekhnika, ekonomika, issue 28, pp. 65-71.

4. Merkur'eva, E. K., 1977. Geneticheskie osnovy selektsii v skotovodstve [Genetic bases of selection in livestock]. Moskva: Kolos.

5. Moskalenko, L. P., Furaeva, N. S. and Zvereva, E. A., 2013. Kompleksnaya otsenka vliyaniya geneticheskikh i paratipicheskikh faktorov na produktivnoe dolgoletie golshtinizirovannykh korov yaroslavskoy porody [Comprehensive assessment of genetic and paratypical factors influence on the productive longevity of Holsteinized cows of Yaroslavl breed]. Vestnik APK Verkhnevolzh'ya, no. 3(23), pp. 41-46. 
6. Polupan, Yu. P., 2014. Efektyvnist dovichnoho vykorystannia koriv riznykh krain selektsii [Effectiveness of cows lifetime use in different countries of selection]. Visnyk Sumskoho natsionalnoho ahrarnoho universytetu. Seriia "Tvarynnytstvo", issue 2/2 (25), pp. 14-20.

7. Fedorovych, V. V., 2015. Zalezhnist molochnoi produktyvnosti koriv ukrainskoi chorno-riaboi molochnoi porody vid promiriv yikh statei tila pislia pershoho otelennia [Dependence of milk productivity of cows Ukrainian Black-and-White dairy breed on measurements of their body parts after first calving]. Visnyk Sumskoho natsionalnoho ahrarnoho universytetu. Seriia "Tvarynnytstvo", issue 2(27), pp. 80-86.

8. Khmelnychyi, L. M., 2004. Bazhanyi typ - mira otsinky molochnoi khudoby za eksterierom [The desired type - measure of dairy cattle assessment by conformation]. Visnyk Ukrainskoho tovarystva henetykiv i selektsioneriv, no. 1, pp. 72-83.

9. Khmelnychyi, L. M., 2010. Bazhanyi typ yak kryterii doboru koriv molochnoi khudoby za eksterierom [Desired type as a criterion for selecting dairy cattle by conformation]. Visnyk Sumskoho NAU, issue 10(18), pp. 137-149.

10. Khmelnychyi, L. M., 2003. Eksteriernyi typ ta produktyvnist koriv ukrainskoi chorno-riaboi molochnoi porody [Conformation type and productivity of cows Ukrainian Black-and-White dairy breed]. Naukovo-tekhnichnyi biuleten Instytutu tvarynnytstva UAAN. Kharkiv, no. 84, pp. 142-146.

11. Khmelnychyi, L. M., 2013. Praktychnyy dosvid, stan ta perspektyva vykorystannya metodyky liniynoyi klasyfikatsiyi koriv molochnoyi khudoby v Ukrayini [Practical experience, status and prospects of using linear classification method of cows dairy cattle in Ukraine]. Visnyk Sums'koho natsional'noho ahrarnoho universytetu. Seriya "Tvarynnytstvo", issue 7(23), pp. 11-19.

12. Khmelnychyi, L. M., 2009. Realizatsiia spadkovosti buhaiv-plidnykiv u spivvidnosnii minlyvosti liniinoi otsinky z molochnoiu produktyvnistiu koriv u vikovii dynamitsi laktatsii [Implementation inheritance of sires in comparable variability of linear estimation with milk productivity of cows in lactations age dynamics]. Rozvedennia i henetyka tvaryn. K.: Ahrarna nauka, no. 43, pp. 329-339.

13. Khmelnychyi, L. M. and Bardash, D. O., 2019. Indicators longevity of cows Ukrainian Red-and-White dairy breed depending on a share of inheritance of Holstein breed [Pokaznyky dovholittia koriv ukrainskoi chervono-riaboi molochnoi porody zalezhno vid chastky spadkovosti holshtynskoi porody]. Visnyk Sumskoho natsionalnoho ahrarnoho universytetu. Seriia "Tvarynnytstvo», issue 4(39), pp. 13-19. doi: https://doi.org/10.32845/bsnau.Ivst.2019.4.2

14. Khmelnychyi, L. M. and Vechorka, V. V., 2015. Vlijanie linejnyh priznakov tipa, harakterizujushhih sostojanie konechnostej, na dlitel'nost' ispol'zovanija korov ukrainskoj cherno-pestroj molochnoj porody [Influence of linear type traits characterizing condition of limbs, on duration use of cows Ukrainian Black-and-White Dairy breed]. Genetika i razvedenie zhivotnyh: Sankt-Peterburg, Pushkin, "OO Reklamnoe bjuro "AZ", no. 2, pp. 36-39.

15. Khmel'nichiy, L. M. and Vecherka V. V., 2015. Pozhiznennaya produktivnost' i dlitel'nost' ispol'zovaniya korov ukrainskoy krasno-pestroy molochnoy porody raznykh genotipov [Lifetime productivity and duration of use cows Ukrainian Red-and-White dairy breed of different genotypes]. In: All-Russian Institute of Animal Husbandry named after academician L. K. Ernst, Ways to extend the productive life of dairy cows based on the optimization of breeding, keeping and feeding technologies, Proceedings of the International conference, Dubrovitsy, May 28-29, 2015. pp. 159-162.

16. Khmelnychyi, L. M. and Vechorka, V. V., 2014. Vikova minlyvist koreliatsii mizh nadoiem ta liniinoiu otsinkoiu typu korivpervistok ukrainskykh chorno- ta chervono-riaboi molochnykh porid [Age variability of correlations between milk yield and linear assessment of type cows firstborn of Ukrainian Black- Red-and-White dairy breeds]. Tekhnolohiia vyrobnytstva i pererobky produktiv tvarynnytstva. Zbirnyk naukovykh prats BNAU. Bila Tserkva, no. 1(116), pp. 84-87.

17. Khmelnychyi, L. M. and Vechorka, V. V., 2018. Vplyv otsinky liniinykh oznak typu, yaki kharakteryzuiut stan kintsivok, na tryvalist zhyttia koriv ukrainskykh chervono-riaboi ta chorno-riaboi molochnykh porid [Influence of linear type traits assessment, that characterize condition of limbs, on the lifetime of cows Ukrainian Red- and Black-and-White dairy breeds]. Visnyk Sumskoho natsionalnoho ahrarnoho universytetu. Seriia "Tvarynnytstvo", issue 2(34), pp. 20-26.

18. Khmelnychyi, L. M. and Vechorka, V. V., 2008. Osoblyvosti budovy tila koriv ukrainskoi chorno-riaboi molochnoi ta holshtynskoі порід [Features of cow's body structure of Ukrainian Black-and-White dairy and Holstein breed]. Rozvedennia $i$ henetyka tvaryn, issue 42, pp. 318-326.

19. Khmelnychyi, L. M., and Vechorka, V. V., 2015. Pokaznyky dovichnoi produktyvnosti koriv ukrainskoi chervono-riaboi molochnoi porody riznykh henotypiv [Indicators of cow's lifetime productivity of Ukrainian Red-and-White dairy breed of different genotypes]. Naukovo-informatsiinyi visnyk bioloho-tekhnolohichnoho fakultetu. Kherson: KhDAU, VTs «Kolos», issue 5, pp. 45-46.

20. Khmelnychyi, L. M. and Vechorka, V. V., 2015. Tryvalist zhyttia koriv ukrainskoi chorno-riaboi molochnoi porody v zalezhnosti vid rivnia liniinoi otsinky morfolohichnykh oznak vymeni [Lifetime of cows Ukrainian Black-and-White dairy breed depending on linear assessment level of udder morphological traits]. Naukovo-teoretychnyi zbirnyk Zhytomyrskoho natsionalnoho ahroekolohichnoho universytetu, no. 2(52), vol. 3, pp. 57-62.

21. Khmelnychyi, L. M., Ladyka, V. I., Polupan, Yu. P., Bratushka, R. V., Pryima, S. V. and Vechorka, V. V., 2016. Liniina klasyfikatsiia koriv molochnykh i molochno-miasnykh porid za typom [Linear classification of dairy and dairy-meat cows by type]. (Metodychni vkazivky) 2-e vyd., pererob. i dop. Sumy : Sumskyi Natsionalnyi Ahrarnyi Universytet.

22. Khmelnychyi, L. M. and Loboda, V. P., 2014. Otsenka vliyaniya nasledstvennykh faktorov na pokazateli pozhiznennoy produktivnosti korov ukrainskoy krasno-pestroy molochnoy porody [Assessment of hereditary factors influence on lifetime productivity indicators of cows Ukrainian Red-and-White Dairy breed]. Aktual'nye problemy intensivnogo razvitiya zhivotnovodstva: sbornik nauchnykh trudov Belorusskoy gos. sel'khoz. akademii. Gorki : BGSKhA, issue 17(2), pp. 159-165. 
23. Khmelnychyi, L. M. and Loboda, V. P., 2014. Udoskonalennia stada z rozvedennia ukrainskoi chervono-riaboi molochnoi porody za pokaznykamy dovichnoi produktyvnosti [Improving the herd for reproduction Ukrainian Red-and-White dairy breed for lifetime productivity indicators]. Visnyk Sumskoho natsionalnoho ahrarnoho universytetu. Seriia: «Tvarynnytstvo», issue 2/1 (24), pp. 9197.

24. Khmelnychyi, L. M., Salohub, A. M., Bondarchuk, V. M. and Loboda, V. P., 2015. Tryvalist vykorystannia ta dovichna produktyvnist koriv zalezhno vid metodiv pidboru ta buhaiv-plidnykiv ukrainskoi chervono-riaboi molochnoi porody [Duration of use and cow's lifetime productivity depending on selection methods and sires of Ukrainian Red-and-White dairy breed]. Visnyk Sumskoho natsionalnoho ahrarnoho universytetu. Seriia "Tvarynnytstvo", issue 6(28), pp. 65-70.

25. Khmelnychyi, L. M., Salohub, A. M., Shevchenko, A. P. and Khmelnychyi, S. L., 2012. Minlyvist dovichnoi produktyvnosti koriv ukrainskoi chorno-riaboi molochnoi porody zalezhno vid henealohichnykh formuvan [Variability lifetime productivity of cows Ukrainian Black-and-White dairy breed based on genealogical groups]. Visnyk Sumskoho natsionalnoho ahrarnoho universytetu. Seriia "Tvarynnytstvo", issue 10(20), pp. 12-17.

26. Chechenikhina, O. S., 2014. Vliyanie bykov-proizvoditeley na produktivnoe dolgoletie docherey [Influence of sires on daughter's productive longevity]. Agrarnyy nauchnyy zhurnal, no. 11, pp. 42-46.

27. Caraviello, D. Z., Weigel, K. A., and Gianola, D., 2004. Analysis of the Relationship between type traits and functional survival in US Holstein cattle using a Weibull proportional Hazards model. J. Dairy Sci., 87(8):2677-2686. DOI: 10.3168 / jds.S0022-0302 (04) 73394-9

28. Daliri, Z., Hafezian, S. H., Shad Parvar, A., and Rahimi. G., 2008. Genetic Relationships among longevity, milk production and linear type traits in Iranian Holstein cattle. J. of Anim. and Vet. Advances. 7(4):512-515.

29. Du Toit, J., Van Wyk, J. B., and Maiwashe, A., 2012. Relationships between functional herd life and conformation traits in the South African Jersey breed. South African Journal of Animal Science. 42 (1):47-54. DOI: 10.4314/sajas.v42i1.6

30. Elisandra, Lurdes Kern, Jaime Araújo Cobuci, Cláudio Napolis Costa, Concepta Margaret, McManus Pimentel. 2014. Factor analysis of linear type traits and their relation with longevity in Brazilian Holstein cattle. Asian Australasian Journal of Animal Sciences . 27(6):784-790.

31. ICAR Guidelines for Conformation Recording of Dairy Cattle, Beef Cattle and Dairy Goats, 1/76. Section - 5, Conformation Recording, version June, 2018. [Електронний ресурс]. - Режим доступу: https://www.icar.org/Guidelines/05-Conformation-Recording.pdf

32. Sewalem, A., Kistemaker, G. J., and Van Doormaal, B. J., 2005. Relationship between type traits and longevity in Canadian Jerseys and Ayrshires using a Weibull Proportional Hazards Model. Journal of Dairy Science, 4:1552-1560.

33. Theron, H. E., and Mostert, B. E., 2004. Genetic analyses for conformation traits in South African Jersey and Holstein cattle. S. Afr. J. Anim. Sci., 34(6): 47-49.

34. Zavadilová, L., Němcová, E., and Štípková, M., 2011. Effect of type traits on functional longevity of Czech Holstein cows estimated from a Cox proportional hazards model. Journal of Dairy Science. 8:4090-4099.

\section{Список використаної літератури:}

1. Климов Н. Н., Танана Л. А., Василец Т. М. Влияние паратипических факторов на продуктивное долголетие коров белорусской чёрно-пёстрой породы. Ученые записки учреждения образования "Витебская ордена "Знак почета" государственная академия ветеринарной медицины". 2010. Т. 46. № 1-2. С. 142-145.

2. Клопенко Н. І. Генетична детермінація господарського використання корів молочного напряму продуктивності за вбирного схрещування / Н.І.Клопенко, Р.В.Ставецька // Технологія виробництва і переробки продукції тваринництва: Зб. наук. праць Білоцерк. нац. аграр. ун-т.- Біла Церква, 2015. Вип. №1. С. 23-28.

3. Мазур Н. П. Продуктивне довголіття корів української чорно-рябої молочної породи різних екстер'єрних та виробничих типів. Подільський вісник: сільське господарство, техніка, економіка. 2018. Вип. 28. С. 65-71.

4. Меркурьева Е. К. Генетические основы селекции в скотоводстве. М.: Колос, 1977. 240 с.

5. Москаленко Л. П., Фураева Н. С., Зверева Е. А. Комплексная оценка влияния генетических и паратипических факторов на продуктивное долголетие голштинизированных коров ярославской породы. Вестник АПК Верхневолжья. 2013. № 3 (23). С. 41-46.

6. Полупан Ю. П. Ефективність довічного використання корів різних країн селекції. Вісник Сумського національного аграрного університету. Серія»Тваринництво». 2014. Вип. 2/2 (25). С. 14-20.

7. Федорович В. В. Залежність молочної продуктивності корів української чорно-рябої молочної породи від промірів їх статей тіла після першого отелення. Вісник Сумського національного аграрного університету. Серія : Тваринництво. 2015. Вип. 2 (27). С. 80-86.

8. Хмельничий Л. М. Бажаний тип - міра оцінки молочної худоби за екстер'єром. Вісник Українського товариства генетиків і селекціонерів. 2004. № 1. Том. 2. С. 72-83.

9. Хмельничий Л. М. Бажаний тип як критерій добору корів молочної худоби за екстер'єром. Вісник Сумського НАУ. Серія “Тваринництво”. - 2010. - 10 (18). - С. 137-149.

10. Хмельничий Л. М. Екстер'єрний тип та продуктивність корів української чорно-рябої молочної породи. Науково-технічний бюлетень Інституту тваринництва УААН. Харків. 2003. №. 84. С. 142-146.

11. Хмельничий Л. М. Практичний досвід, стан та перспектива використання методики лінійної класифікації корів молочної худоби в Україні. Вісник Сумського національного аграрного університету. Серія «Тваринництво». 2013. Вип. 7 (23). С. $11-19$. 
12. Хмельничий Л. М. Реалізація спадковості бугаїв-плідників у співвідносній мінливості лінійної оцінки з молочною продуктивністю корів у віковій динаміці лактацій. Розведення і генетика тварин. К.: Аграрна наука. 2009. Вип. 43. С. $329-339$.

13. Хмельничий Л. М., Бардаш Д. О. Показники довголіття корів української червоно-рябої молочної породи залежно від частки спадковості голштинської породи. Вісник Сумського національного аграрного університету. Серія «Тваринництво». 2019. Вип. 4(39). C.13-19. DOI: https://doi.org/10.32845/bsnau.lvst.2019.4.2

14. Хмельничий Л. М., Вечерка В. В. Влияние линейных признаков типа, характеризующих состояние конечностей, на длительность использования коров украинской черно-пестрой молочной породы. Генетика и разведение животных: СанктПертербург, Пушкин, «ОО Рекламное бюро “АЗ”». 2015. № 2. С. 36-39.

15. Хмельничий Л. М., Вечерка В. В. Пожизненная продуктивность и длительность использования коров украинской красно-пестрой молочной породы разных генотипов. Пути продления продуктивной жизни молочных коров на основе оптимизации разведения, технологий содержания и кормления животных : материалы междунар. науч.- практ. конф., (28-29 мая, пос. Дубровицы) / ВИЖ им. Л. К. Эрнста, 2015. С. 159-162.

16. Хмельничий Л. М., Вечорка В. В. Вікова мінливість кореляцій між надоєм та лінійною оцінкою типу корів-первісток українських чорно- та червоно-рябої молочних порід. Технологія виробництва і переробки продуктів тваринництва. Збірник наукових праць БНАУ. 2014. № 1 (116). С. 84-87.

17. Хмельничий Л. М., Вечорка В. В. Вплив оцінки лінійних ознак типу, які характеризують стан кінцівок, на тривалість життя корів українських червоно-рябої та чорно-рябої молочних порід. Вісник Сумського національного аграрного університету. Серія : Тваринництво. 2018. Вип. 2 (34). С. 20-26.

18. Хмельничий Л. М., Вечорка В. В. Особливості будови тіла корів української чорно-рябої молочної та голштинської порід. Розведення і генетика тварин. К.: Аграрна наука. 2008. Вип. 42. С. 318-326.

19. Хмельничий Л. М., Вечорка В.В.Показники довічної продуктивності корів української червоно-рябої молочної породи різних генотипів. Науково-інформаційний вісник біолого-технологічного факультету. Херсон: ХДАУ, ВЦ «Колос». 2015. Вип. 5. С. 4546.

20. Хмельничий Л. М., Вечорка В.В.Тривалість життя корів української чорно-рябої молочної породи в залежності від рівня лінійної оцінки морфологічних ознак вимені. Науково-теоретичний збірник Житомирського національного агроекологічного університету. - ЖНАЕУ. - 2015. - №.2 (52) - Т. 3 - С. 57-62.

21. Хмельничий Л. М., Ладика В. І., Полупан Ю. П., Братушка Р. В., Прийма С. В., Вечорка В. В. Лінійна класифікація корів молочних і молочно-м'ясних порід за типом. (Методичні вказівки) - 2-е вид., перероб. і доп. Суми : Сумський національний аграрний університет, 2016. 27 с.

22. Хмельничий Л. М., Лобода В. П. Оценка влияния наследственных факторов на показатели пожизненной продуктивности коров украинской красно-пестрой молочной породы. Актуальные проблемы интенсивного развития животноводства: сборник научных трудов Белорусской гос. сельхоз. академии. Горки: БГСХА. 2014. Вып. 17. Ч. 2. С. 159-165.

23. Хмельничий Л. М., Лобода В. П. Удосконалення стада з розведення української червоно-рябої молочної породи за показниками довічної продуктивності. Вісник Сумського національного аграрного університету. Серія «Тваринництво». 2014. Вип. 2/1 (24). С. 91-97.

24. Хмельничий Л. М., Салогуб А. М., Бондарчук В. М., Лобода В. П. Тривалість використання та довічна продуктивність корів залежно від методів підбору та бугаїв-плідників української червоно-рябої молочної породи. Вісник Сумського національного аграрного університету. Серія «Тваринництво». 2015. Вип. 6 (28). С. 65-70.

25. Хмельничий Л. М., Салогуб А. М., Шевченко А. П., Хмельничий С. Л. Мінливість довічної продуктивності корів української чорно-рябої молочної породи залежно від генеалогічних формувань. Вісник Сумського національного аграрного університету. Серія «Тваринництво». 2012. Вип. 10 (20). С. 12-17.

26. Чеченихина О. С. Влияние быков-производителей на продуктивное долголетие дочерей. Аграрный научный журнал. 2014. № 11. С. 42-46.

27. Caraviello D. Z., Weigel K. A., and Gianola D. Analysis of the Relationship between type traits and functional survival in US Holstein cattle using a Weibull proportional Hazards model. J. Dairy Sci., 2004. Vol 87(8). P. 2677-2686. DOI:10.3168 / jds.S00220302 (04) 73394-9

28. Daliri Z., Hafezian S. H., Shad Parvar A., Rahimi G. Genetic Relationships among Longevity, Milk Production and Linear Type Traits in Iranian Holstein Cattle. Journal of Animal and Veterinary Advances. 2008. Vol. 7. Issue: 4. P. 512-515.

29. Du Toit J., Van Wyk J. B., and Maiwashe A. Relationships between functional herd life and conformation traits in the South African Jersey breed. South African Journal of Animal Science. 2012. Vol. 42 (No. 1). P. 47-54. DOI: 10.4314/sajas.v42i1.6

30. Elisandra, Lurdes Kern, Jaime Araújo Cobuci, Cláudio Napolis Costa, Concepta Margaret, McManus Pimentel. Factor analysis of linear type traits and their relation with longevity in Brazilian Holstein cattle. Asian Australasian Journal of Animal Sciences . 06/2014; 27(6):784-790.

31. ICAR Guidelines for Conformation Recording of Dairy Cattle, Beef Cattle and Dairy Goats, 1/76. Section - 5, Conformation Recording, version June, 2018. [Електронний ресурс]. - Режим доступу: https://www.icar.org/Guidelines/05-Conformation-Recording.pdf

32. Sewalem A., Kistemaker G. J., Van Doormaal B. J. Relationship Between Type Traits and Longevity in Canadian Jerseys and Ayrshires Using a Weibull Proportional Hazards Model. Journal of Dairy Science, 2005. Vol. 88, Issue 4, p.1552-1560.

33. Theron H. E., Mostert B. E. Genetic analyses for conformation traits in South African Jersey and Holstein cattle. S. Afr. J. Anim. Sci. 2004, 34 (6): 47-49. 
34. Zavadilová L., Němcová E., Štípková M. Effect of type traits on functional longevity of Czech Holstein cows estimated from a Cox proportional hazards model. Journal of Dairy Science. 2011. Vol. 94. Issue 8. P. 4090-4099.

Хмельничий Леонтій Михайлович, доктор сільськогосподарських наук, профресор

Вечорка Вікторія Вікторівна, доктор сільськогосподарських наук, профессор

Сумський національний аграрний університет (Суми, Україна)

Вплив описових лінійних ознак вимені на тривалість життя корів українських молочних порід

Дослідженні проведені для визначення зв'язку між оцінкою лінійних ознак вимені та тривалістю життя корів. Експерименти проведені у стаді племінного заводу АФ "Маяк" Золотоніського району Черкаської області на поголів"ї корів українських червоно-рябої (УЧерР) та чорно-рябої (УЧорР) молочних порід. Оцінка корів-первісток за екстер'єрним типом проведена за методикою лінійної класифрікації. Встановлено, що корови з вищими оцінками за стан розвитку морфологічних ознак вимені мають довшу тривалість життя у порівнянні з тваринами, оцінених нижчим балом. Різниия між коровами, оціненими в один та дев'ять балів за ознаку прикріплення передньої частини вимені, досить істотна і становила 939 (УЧерР) та 710 (УЧорР) днів. Різниця між найнижчою та найвищою оцінками за ознакою висоти прикріплення задніх часток вимені становила 687 (УЧерР) та 878 (УЧорР) днів. Тварини з оцінкою за розвиток центральної зв'язки вимені нижчою від середньої (1-4 бали) використовуються від 1675 до 1832 (УЧерР) та від 1535 до 1810 (УЧорР) днів відповідно до оцінюваних порід. Корови з оцінкою дев'ять балів відрізняються вищою тривалістю життя - 2377 днів, перевищуючи корів з самою низькою оиінкою на 702 дні (УЧерР) та 2322 дні з достовірним перевищенням на 785 днів (УЧорР). Різниия між середньою тривалістю життя корів з оцінкою дев'ять балів та оцінкою в один бал за глибину вимені становить у корів УЧерР 618 днів, у УЧорР - 762 дні. Доведено, що найдовше використовувалися у стаді корови з оиінками за розташування передніх дійок від n'яти до дев'яти балів, а істотне зниження показника тривалості життя у корів розпочинається з оцінкою за цю ознаку від трьох до одного балу. Таким чином, оцінка корів українських червоно-рябої та чорно-рябої молочних порід за методикою лінійної класифікації підтвердила, що бажаний розвиток морфологічних ознак вимені є запорукою тривалого життя корів у сучасних технологічних умовах виробництва молока.

Ключові слова: лінійна оцінка, українська червоно-ряба молочна порода, українська чорно-ряба молочна порода, ознаки вимені, тривалість життя

Дата надходження до редакції: 04. 10.2020 р. 